\title{
The use of biological drugs in psoriasis patients prior to pregnancy, during pregnancy and lactation: a review of current clinical guidelines
}

\author{
Witold Owczarek ${ }^{1}$, Irena Walecka², Aleksandra Lesiak ${ }^{3}$, Rafał Czajkowski ${ }^{4}$, Adam Reich $^{5}$, Iwona Zerda ${ }^{6}$, Joanna Narbutt ${ }^{3}$ \\ 'Department of Dermatology, Military Institute of Medicine, Warsaw, Poland \\ ${ }^{2}$ Department of Dermatology, Centre of Postgraduate Medical Education, Central Clinical Hospital of the Ministry of Interior and \\ Administration, Warsaw, Poland \\ ${ }^{3}$ Department of Dermatology, Paediatric and Oncological Dermatology, Medical University of Lodz, Lodz, Poland \\ ${ }^{4}$ Department of Dermatology and Venerology, Faculty of Medicine, Ludwik Rydygier Medical College in Bydgoszcz, Nicolaus Copernicus \\ University in Torun, Poland \\ ${ }^{5}$ Department of Dermatology, University of Rzeszow, Rzeszow, Poland \\ ${ }^{6}$ CEESTAHC, Krakow, Poland
}

Adv Dermatol Allergol 2020; XXXVII (6): 821-830

DOI: https://doi.org/10.5114/ada.2020.102089

\begin{abstract}
Introduction: Information on the possibility of using biological drugs in psoriasis patients planning to conceive, patients who are pregnant or during lactation is limited.

Aim: Presenting recommendations published in clinical guidelines regarding the use of biological drugs - adalimumab, brodalumab, certolizumab pegol, etanercept, guselkumab, infliximab, ixekizumab, risankizumab, secukinumab, tildrakizumab, and ustekinumab, by psoriasis patients in the period of planning pregnancy, during pregnancy or during lactation.

Material and methods: The paper was based on a comprehensive review of over 40 websites of HTA agencies, dermatological associations worldwide and medical databases (PubMed, Embase), the objective of which was to identify clinical guidelines relating to biological treatment of women of childbearing potential, published after 2018, which used GRADE - a system for rating the quality of a body of evidence.

Findings: Certolizumab pegol is recommended in women who are planning to conceive. Furthermore, guidelines indicate other TNF- $\alpha$ inhibitors as possible treatment. Certolizumab pegol is also recommended as first-line treatment in pregnant patients. Furthermore, for trimesters 2 and 3, guidelines allow using other TNF- $\alpha$ inhibitors. Treatment with secukinumab and ustekinumab should be discontinued when planning pregnancy or when pregnancy was diagnosed. Biological treatment during pregnancy and lactation (continuation or initiation of treatment) can be used only after an analysis of risks and benefits has been conducted.

Conclusions: TNF- $\alpha$ inhibitors seem to be the safest and most researched biological drugs used in psoriasis treatment of patients planning to conceive, during pregnancy or lactation. Given its non-existent or minimal placental permeability, most likely the safest alternative is certolizumab pegol.
\end{abstract}

Key words: pregnancy, lactation, psoriasis, biological treatment, tumor necrosis factor- $\alpha$ inhibitors.

\section{Introduction}

Psoriasis is a chronic, systemic, inflammatory skin disease affecting approx. 1-3\% of the general population $[1,2]$. Most patients have a mild disease and skin lesions require only topical medication. The remaining $20-30 \%$ of patients have moderate to severe psoriasis requiring systemic treatment, including biological treatment [3]. Psoriasis occurs in people of different ages, with the same frequency in both sexes, but in $75 \%$ of cases it occurs before the age of 45 . A significant percentage of patients are therefore young people, including women of childbearing age [1, 2].

Address for correspondence: Prof. Irena Walecka MD, PhD, Dermatology Department, Centre of Postgraduate Medical Education, Central Clinical Hospital MSWiA, 137 Wołoska St, 02-507 Warsaw, Poland, phone: +48 2250814 82, +48 225081480 ,

e-mail: irena.walecka@cskmswia.pl

Received: 15.09.2020, accepted: 14.10.2020. 
The course of the disease and its impact on the quality of life can differ significantly depending on the patient's sex. That may result from biological, e.g. hormonal, as well as psychosocial differences. Women declare a lower level of happiness (by $18.5 \%$ in women and $11.3 \%$ in men compared to the general population), experience stress more often (> 60\% women vs. $42 \%$ men), loneliness (women: 25-28\%, men: 19-24\%), experience stigma or reduced sexual activity (women: 33\%, men: 19\%) compared to men [4]. The differences between women's and men's physiology must be taken into account in diagnostics, prognosis and treatment of the disease. The medical language uses the term "gender medicine", which consists in an individual approach to patients, taking into account their differences resulting from both different physiology and different psychosocial aspects.

Pregnancy and the postpartum period is a special time due to the numerous physiological and hormonal changes occurring in the woman's body. Despite the high prevalence of psoriasis, data on the impact of pregnancy on the course of the disease, and vice versa, on the impact of the disease on pregnancy, are limited. Many women experience stabilisation (18\%) or improvement (56\%) of skin symptoms during pregnancy, however in about a quarter (26\%) of patients, its course may significantly exacerbate [5]. Moreover, over $50 \%$ of women experience a sudden exacerbation of the disease in the postpartum period [4]. Currently, no clear evidence of a negative effect of psoriasis on the foetus and pregnancy is available, however, some studies indicate that the risk of spontaneous abortions, an increased incidence of caesarean sections, or a lower birth weight of a child may be greater in this population [6]. In women whose symptoms are controlled, discontinuing systemic pharmacotherapy during pregnancy is a sensible strategy. However, in the case of severe illness, it may be necessary to continue treatment, including biological therapy. In each case, the risk associated with the teratogenic or other adverse effects of the drug on the foetus should be taken into account, balancing them with the risk associated with the lack of disease control on the course of pregnancy and the postpartum period and the mother's health condition [7].

Biological drugs used to treat plaque psoriasis belong to several groups: TNF- $\alpha$ inhibitors (adalimumab, certolizumab pegol, etanercept, infliximab), drugs blocking the p40 IL-12/IL-23 subunit (ustekinumab), anti-IL-17A antibodies (brodalumab, ixekizumab, secukinumab), and anti-IL-23 antibodies (guselkumab, risankizumab, tildrakizumab). These drugs are IgG monoclonal antibodies, differing in structure, half-life and placental permeability.

Currently, all the drugs listed above are available in Poland (except brodalumab), however only some of them are reimbursed from public funds under a drug programme: The B.47 "Treatment of moderate to severe plaque psoriasis" drug programme provides for the pos- sibility of using the following biological drugs financed in Poland: adalimumab, etanercept, ixekizumab, infliximab, secukinumab, and ustekinumab. Currently pregnancy and lactation are the criteria for exclusion from the B.47 drug programme, and contraception is recommended [8].

The summary of product characteristics (SPC) applicable in the European Union for biological drugs with marketing authorisation in psoriasis treatment provides descriptive information whether the product may be used in women planning to conceive or pregnant women. Applicable recommendations advocate the use of contraception in women at childbearing age receiving biological therapy. According to the information provided in the relevant SPC, adalimumab, etanercept and infliximab should only be used during pregnancy if clearly needed, while in other cases the drug should only be used if clinically justified. According to guidelines, breastfeeding is possible for women taking adalimumab [9] and certolizumab pegol [10] and is not recommended in other cases (Table 1). When choosing a biological treatment during pregnancy, it should be borne in mind that the impact of these drugs can affect not only the mother, but also the foetus. At an early stage of the pregnancy one should also take the into account the potential teratogenic effect, possible foetal malformations, and the development of the immune system, in the case of which the critical period is the period from the third trimester to the $6^{\text {th }}$ month of life of the newborn [11-13]. According to the characteristics of individual biological drugs, in neonates exposed in utero to biological agents, exposure to live vaccines should be postponed, in particular vaccination against tuberculosis.

The fact that individual regulatory agencies use different policies and categorise the risks associated with the use of treatment differently does not facilitate the doctor's decision-making process regarding the implementation (or continuation) of appropriate systemic therapy in pregnant or breastfeeding women. In the past, the Food and Drug Administration (FDA) had used 5 categories for the safety of drugs during pregnancy (Table 2) [14]. Currently, however, the FDA has moved away from this form of categorisation in favour of more detailed, descriptive recommendations. At the same time the Australian Therapeutic Goods Administration (TGA) uses categories similar to the categories applicable in the US in the past. However some entries regarding the same substances differ significantly between the agencies (Tables 1 and 2) [9-11, 14-23].

Despite the constantly expanding expertise on the safety of use of biological therapies in women of childbearing age and the growing interest in the subject, only few reports or registers on the subject exist. Hence, there is a significant need to synthesise evidence and develop an interdisciplinary approach between doctors representing different medical specialities. 
Table 1. Recommendations for treatment in women of child-bearing potential, pregnant and breastfeeding included in the summaries of product characteristics

\begin{tabular}{|c|c|c|c|c|c|c|c|}
\hline \multirow[t]{2}{*}{ Drug name } & \multirow{2}{*}{$\begin{array}{l}\text { Marketing } \\
\text { authorisation } \\
\text { indication }\end{array}$} & \multirow[t]{2}{*}{$\begin{array}{l}\text { Type of } \\
\text { antibody }\end{array}$} & \multicolumn{3}{|c|}{$\begin{array}{l}\text { Recommendations in the SPCs issued by the European } \\
\text { Medicines Agency (EMA) }\end{array}$} & \multicolumn{2}{|c|}{$\begin{array}{l}\text { Classification of the drug } \\
\text { for pregnant women }\end{array}$} \\
\hline & & & $\begin{array}{l}\text { Women of child-bearing } \\
\text { potential }\end{array}$ & Pregnancy & Breastfeeding & FDA [15] & TGA [16] \\
\hline $\begin{array}{l}\text { Infliximab } \\
{[16]}\end{array}$ & $\begin{array}{l}A A ; R A ; C D ; \\
\text { UC; AS; PSA }\end{array}$ & $\begin{array}{l}\text { Chimeric } \\
\text { monoclonal } \\
\text { IgG1 } \\
\text { antibody }\end{array}$ & $\begin{array}{l}\text { Contraception is } \\
\text { recommended until at } \\
\text { least } 6 \text { months after } \\
\text { the end of treatment }\end{array}$ & $\begin{array}{l}\text { Should only } \\
\text { be used } \\
\text { during } \\
\text { pregnancy if } \\
\text { clearly needed }\end{array}$ & $\begin{array}{l}\text { Not recommended } \\
\text { ( } \geq 6 \text { months } \\
\text { following completed } \\
\text { treatment) }\end{array}$ & $\mathrm{B}$ & C \\
\hline $\begin{array}{l}\text { Etanercept } \\
\text { [9] }\end{array}$ & $\begin{array}{l}\text { AA; RA; JIA; } \\
\text { PSA; AS }\end{array}$ & $\begin{array}{l}\text { Soluble TNF } \\
\text { receptor } \\
\text { Il fusion } \\
\text { protein } \\
\text { with Fc lgG1 } \\
\text { domain } \\
\text { (TNFR2/p75) }\end{array}$ & $\begin{array}{l}\text { Contraception is } \\
\text { recommended until at } \\
\text { least } 3 \text { weeks after the } \\
\text { end of treatment }\end{array}$ & $\begin{array}{l}\text { Use is not } \\
\text { recommended } \\
\text { (should } \\
\text { only be } \\
\text { used during } \\
\text { pregnancy } \\
\text { if clearly } \\
\text { needed) }\end{array}$ & $\begin{array}{l}\text { Decision must be } \\
\text { made whether to } \\
\text { discontinue breast- } \\
\text { feeding or to } \\
\text { discontinue Enbrel } \\
\text { therapy, taking } \\
\text { into account } \\
\text { the benefit of } \\
\text { breast-feeding for } \\
\text { the child and the } \\
\text { benefit of therapy } \\
\text { for the woman }\end{array}$ & $\mathrm{B}$ & $\mathrm{D}$ \\
\hline $\begin{array}{l}\text { Adalimumab } \\
{[10]}\end{array}$ & $\begin{array}{c}\text { AA; RA; JIA; } \\
\text { CD; AS; PsA; } \\
\text { UC }\end{array}$ & $\begin{array}{l}\text { Recombinant } \\
\text { monoclonal } \\
\text { IgG1 } \\
\text { antibody }\end{array}$ & $\begin{array}{l}\text { Contraception is } \\
\text { recommended until at } \\
\text { least } 5 \text { months after } \\
\text { the end of treatment }\end{array}$ & $\begin{array}{l}\text { Should only } \\
\text { be used } \\
\text { during } \\
\text { pregnancy if } \\
\text { clearly needed }\end{array}$ & $\begin{array}{c}\text { Can be } \\
\text { used during } \\
\text { breastfeeding }\end{array}$ & B & $C$ \\
\hline $\begin{array}{l}\text { Certolizumab } \\
\text { pegol [11] }\end{array}$ & $\begin{array}{l}A A ; \text { RA; } A S ; \\
\text { PSA }\end{array}$ & $\begin{array}{c}\text { PEGylated } \\
\text { Fab' } \\
\text { fragment of } \\
\text { a humanized } \\
\text { TNF- } \alpha \\
\text { antibody }\end{array}$ & $\begin{array}{l}\text { Contraception is } \\
\text { recommended until at } \\
\text { least } 5 \text { months after } \\
\text { the end of treatment, } \\
\text { but the need for } \\
\text { treatment of the } \\
\text { woman should also be } \\
\text { taken into account }\end{array}$ & $\begin{array}{l}\text { Should only } \\
\text { be used } \\
\text { during } \\
\text { pregnancy } \\
\text { if clinically } \\
\text { needed }\end{array}$ & $\begin{array}{c}\text { Can be } \\
\text { used during } \\
\text { breastfeeding }\end{array}$ & B & C \\
\hline $\begin{array}{l}\text { Ustekinumab } \\
{[17]}\end{array}$ & $\begin{array}{l}\mathrm{AA}, \mathrm{PsA}, \mathrm{CD} \\
\mathrm{UC}\end{array}$ & $\begin{array}{l}\text { Recombinant } \\
\text { monoclonal } \\
\text { IgG1 anti- } \\
\text { interleukin } \\
\text { (IL)-12/23 } \\
\text { IgG1 } \\
\text { antibody }\end{array}$ & $\begin{array}{l}\text { Contraception is } \\
\text { recommended until at } \\
\text { least } 15 \text { weeks after } \\
\text { the end of treatment }\end{array}$ & $\begin{array}{l}\text { Avoiding } \\
\text { treatment } \\
\text { during } \\
\text { pregnancy is } \\
\text { recommended }\end{array}$ & $\begin{array}{l}\text { Decision to } \\
\text { continue } \\
\text { breastfeeding/ } \\
\text { treatment based } \\
\text { on a risk/benefit } \\
\text { analysis for the } \\
\text { child and the } \\
\text { mother }\end{array}$ & B & B1 \\
\hline $\begin{array}{l}\text { Secukinumab } \\
{[18]}\end{array}$ & AA; PsA; AS & $\begin{array}{c}\text { Recombinant } \\
\text { monoclonal } \\
\text { antibody }\end{array}$ & $\begin{array}{l}\text { Contraception is } \\
\text { recommended until at } \\
\text { least } 20 \text { weeks after } \\
\text { the end of treatment }\end{array}$ & $\begin{array}{l}\text { Avoiding } \\
\text { treatment } \\
\text { during } \\
\text { pregnancy is } \\
\text { recommended }\end{array}$ & $\begin{array}{l}\text { Decision to } \\
\text { continue } \\
\text { breastfeeding/ } \\
\text { treatment based } \\
\text { on a risk/benefit } \\
\text { analysis for the } \\
\text { child and the } \\
\text { mother }\end{array}$ & $B$ & C \\
\hline $\begin{array}{l}\text { Ixekizumab } \\
\text { [19] }\end{array}$ & AA, PsA & $\begin{array}{c}\text { Recombinant } \\
\text { monoclonal } \\
\text { antibody }\end{array}$ & $\begin{array}{l}\text { Contraception is } \\
\text { recommended until at } \\
\text { least } 10 \text { weeks after } \\
\text { the end of treatment }\end{array}$ & $\begin{array}{l}\text { Avoiding } \\
\text { treatment } \\
\text { during } \\
\text { pregnancy is } \\
\text { recommended }\end{array}$ & $\begin{array}{l}\text { Decision to } \\
\text { continue } \\
\text { breastfeeding/ } \\
\text { treatment based } \\
\text { on a risk/benefit } \\
\text { analysis for the } \\
\text { child and the } \\
\text { mother }\end{array}$ & ND & C \\
\hline
\end{tabular}


Table 1. Cont.

\begin{tabular}{|c|c|c|c|c|c|c|c|}
\hline \multirow[t]{2}{*}{ Drug name } & \multirow{2}{*}{$\begin{array}{c}\text { Marketing } \\
\text { authorisation } \\
\text { indication }\end{array}$} & \multirow[t]{2}{*}{$\begin{array}{l}\text { Type of } \\
\text { antibody }\end{array}$} & \multicolumn{3}{|c|}{$\begin{array}{l}\text { Recommendations in the SPCs issued by the European } \\
\text { Medicines Agency (EMA) }\end{array}$} & \multicolumn{2}{|c|}{$\begin{array}{l}\text { Classification of the drug } \\
\text { for pregnant women }\end{array}$} \\
\hline & & & $\begin{array}{l}\text { Women of child-bearing } \\
\text { potential }\end{array}$ & Pregnancy & Breastfeeding & FDA [15] & TGA [16] \\
\hline $\begin{array}{l}\text { Risankizumab } \\
{[20]}\end{array}$ & AA & $\begin{array}{l}\text { Recombinant } \\
\text { monoclonal } \\
\text { antibody } \\
\text { directed } \\
\text { against IL-23 }\end{array}$ & $\begin{array}{l}\text { Contraception is } \\
\text { recommended until at } \\
\text { least } 21 \text { weeks after } \\
\text { the end of treatment }\end{array}$ & $\begin{array}{l}\text { Avoiding } \\
\text { treatment } \\
\text { during } \\
\text { pregnancy is } \\
\text { recommended }\end{array}$ & $\begin{array}{l}\text { Decision to } \\
\text { continue } \\
\text { breastfeeding/ } \\
\text { treatment based } \\
\text { on a risk/benefit } \\
\text { analysis for the } \\
\text { child and the } \\
\text { mother }\end{array}$ & ND & B1 \\
\hline $\begin{array}{l}\text { Guselkumab } \\
{[21]}\end{array}$ & AA & $\begin{array}{l}\text { Recombinant } \\
\text { monoclonal } \\
\text { antibody } \\
\text { directed } \\
\text { against IL-23 }\end{array}$ & $\begin{array}{l}\text { Contraception is } \\
\text { recommended until at } \\
\text { least } 12 \text { weeks after } \\
\text { the end of treatment }\end{array}$ & $\begin{array}{l}\text { Avoiding } \\
\text { treatment } \\
\text { during } \\
\text { pregnancy is } \\
\text { recommended }\end{array}$ & $\begin{array}{l}\text { Decision to } \\
\text { continue } \\
\text { breastfeeding/ } \\
\text { treatment based } \\
\text { on a risk/benefit } \\
\text { analysis for the } \\
\text { child and the } \\
\text { mother }\end{array}$ & ND & B1 \\
\hline $\begin{array}{l}\text { Tildrakizumab } \\
\text { (Ilumetri) [22] }\end{array}$ & AA & $\begin{array}{l}\text { Recombinant } \\
\text { monoclonal } \\
\text { antibody } \\
\text { directed } \\
\text { against IL-23 } \\
\text { p19 }\end{array}$ & $\begin{array}{l}\text { Contraception is } \\
\text { recommended until at } \\
\text { least } 17 \text { weeks after } \\
\text { the end of treatment }\end{array}$ & $\begin{array}{l}\text { Avoiding } \\
\text { treatment } \\
\text { during } \\
\text { pregnancy is } \\
\text { recommended }\end{array}$ & $\begin{array}{l}\text { Decision to } \\
\text { continue } \\
\text { breastfeeding/ } \\
\text { treatment based } \\
\text { on a risk/benefit } \\
\text { analysis for the } \\
\text { child and the } \\
\text { mother }\end{array}$ & ND & B1 \\
\hline $\begin{array}{l}\text { Brodalumab } \\
{[23]}\end{array}$ & AA & $\begin{array}{l}\text { Recombinant } \\
\text { monoclonal } \\
\text { antibody } \\
\text { directed } \\
\text { against IL-17 }\end{array}$ & $\begin{array}{l}\text { Contraception is } \\
\text { recommended until at } \\
\text { least } 12 \text { weeks after } \\
\text { the end of treatment }\end{array}$ & $\begin{array}{l}\text { Avoiding } \\
\text { treatment } \\
\text { during } \\
\text { pregnancy is } \\
\text { recommended }\end{array}$ & $\begin{array}{l}\text { Decision to } \\
\text { continue } \\
\text { breastfeeding/ } \\
\text { treatment based } \\
\text { on a risk/benefit } \\
\text { analysis for the } \\
\text { child and the } \\
\text { mother }\end{array}$ & ND & ND \\
\hline
\end{tabular}

RA - rheumatoid arthritis, CD - Crohn's disease, UC - ulcerative colitis, AS - ankylosing spondylitis, PSA - psoriatic arthritis, AA - alopecia areata, JIA - juvenile idiopathic arthritis, FDA - Food and Drug Administration, TGA - Therapeutic Goods Administration.

\section{Aim}

The objective of this paper is to present recommendations published in clinical guidelines regarding the use of biological drugs - adalimumab, brodalumab, certolizumab pegol, etanercept, guselkumab, infliximab, ixekizumab, risankizumab, secukinumab, tildrakizumab, and ustekinumab in plaque psoriasis patients in the period of planning pregnancy, during pregnancy or lactation.

\section{Material and methods}

The paper is based on a comprehensive review of over 40 websites of HTA (Health Technology Assessment) agencies, dermatological associations/societies worldwide and medical databases (PubMed, Embase) carried out to identify both international and national clinical guidelines. The analysis took into account clinical practice guidelines published after 2018 which used GRADE, i.e. a system for rating the quality of a body of evidence [24]. Finally, 5 doc- uments were selected for further works: the latest version of guidelines issued by the British Association of Dermatologists in 2020 (BAD 2020 [25]), guidelines issued by the American College of Rheumatology in 2020 (ACR 2020 [26] - included as the widest document on the use of biological drugs), Dutch guidelines: Kraaij 2019 [27], Latin American Clinical practice guidelines: Kogan 2019 [28] and German guidelines: Nast 2018 [29]. Grades of Recommendation, Assessment, Development, and Evaluation (GRADE) [24] methodology was used to assess the body of evidence on which the guidelines and recommendations were based. Other, i.e. Australian [30] recommendations were also found, however they did not meet the GRADE conditions, and thus the decision was made against their inclusion, despite the fact that locally they may play a significant opinion-forming role.

Information on the specific pregnancy-related periods (planning to conceive, pregnancy and lactation) was searched for in all of the documents. 
Table 2. Risk categories related to the use of treatment in pregnant women

\begin{tabular}{|c|c|c|c|}
\hline \multicolumn{2}{|r|}{ FDA [14] } & \multicolumn{2}{|r|}{ TGA [15] } \\
\hline Category & Description & Category & Description \\
\hline$A$ & $\begin{array}{l}\text { Adequate and well-controlled studies have failed } \\
\text { to demonstrate a risk to the foetus in the first } \\
\text { trimester of pregnancy (and there is no evidence } \\
\text { of risk in later trimesters) }\end{array}$ & A & $\begin{array}{l}\text { Drugs which have been taken by a large number of } \\
\text { pregnant women and women of childbearing age without } \\
\text { any proven increase in the frequency of malformations } \\
\text { or other direct or indirect harmful effects on the foetus } \\
\text { having been observed }\end{array}$ \\
\hline \multirow[t]{3}{*}{ B } & $\begin{array}{l}\text { Animal reproduction studies have failed to } \\
\text { demonstrate a risk to the foetus and there are no } \\
\text { adequate studies in pregnant women, or there } \\
\text { is evidence of possible adverse effects in animal } \\
\text { studies but this has not been confirmed in studies } \\
\text { with pregnant women }\end{array}$ & B1 & $\begin{array}{l}\text { Drugs which have been taken by only a limited number of } \\
\text { pregnant women and women of childbearing age, without } \\
\text { an increase in the frequency of malformation or other } \\
\text { direct or indirect harmful effects on the human foetus } \\
\text { having been observed. Studies in animals have not shown } \\
\text { evidence of an increased occurrence of foetal damage }\end{array}$ \\
\hline & & B2 & $\begin{array}{l}\text { Drugs which have been taken by only a limited number of } \\
\text { pregnant women and women of childbearing age, without } \\
\text { an increase in the frequency of malformation or other } \\
\text { direct or indirect harmful effects on the human foetus } \\
\text { having been observed. Studies in animals are inadequate } \\
\text { or may be lacking, but available data show no evidence of } \\
\text { an increased occurrence of foetal damage }\end{array}$ \\
\hline & & B3 & $\begin{array}{l}\text { Drugs which have been taken by only a limited number of } \\
\text { pregnant women and women of childbearing age, without } \\
\text { an increase in the frequency of malformation or other } \\
\text { direct or indirect harmful effects on the human foetus } \\
\text { having been observed. Studies in animals have shown } \\
\text { evidence of an increased occurrence of foetal damage, the } \\
\text { significance of which is considered uncertain in humans }\end{array}$ \\
\hline C & $\begin{array}{l}\text { Animal reproduction studies have shown an adverse } \\
\text { effect on the foetus and there are no adequate and } \\
\text { well-controlled studies in pregnant women, but } \\
\text { potential benefits may warrant use of the drug in } \\
\text { pregnant women despite potential risks }\end{array}$ & C & $\begin{array}{l}\text { Drugs which, owing to their pharmacological effects, } \\
\text { have caused or may be suspected of causing, harmful } \\
\text { effects on the human foetus or neonate without } \\
\text { causing malformations. These effects may be reversible. } \\
\text { Accompanying texts should be consulted for further details }\end{array}$ \\
\hline$D$ & $\begin{array}{l}\text { There is positive evidence of the human foetal } \\
\text { risk based on studies in pregnant women, but } \\
\text { potential benefits may warrant use of the drug in } \\
\text { pregnant women despite potential risks }\end{array}$ & D & $\begin{array}{l}\text { Drugs which have caused, are suspected to have caused } \\
\text { or may be expected to cause, an increased incidence of } \\
\text { human foetal malformations or irreversible damage. These } \\
\text { drugs may also have adverse pharmacological effects. } \\
\text { Accompanying texts should be consulted for further details }\end{array}$ \\
\hline$x$ & $\begin{array}{l}\text { Drugs contraindicated in pregnant women. } \\
\text { Studies in pregnant women and animals have } \\
\text { demonstrated that the potential risk of using the } \\
\text { drug is higher than the benefits }\end{array}$ & $x$ & $\begin{array}{l}\text { Drugs which have such a high risk of causing permanent } \\
\text { damage to the foetus that they should not be used in } \\
\text { pregnancy or when there is a possibility of pregnancy }\end{array}$ \\
\hline
\end{tabular}

\section{Findings}

\section{Planning to conceive}

The use of biological drugs in psoriasis patients planning to conceive was referred to in four of the guidelines. All of those documents recommend approaching biological drugs in the period preceding pregnancy with great caution, while the latest BAD 2020 [25] and ACR 2020 [26] guidelines recommend using certolizumab pegol in that period. Similarly, this was described in the NICE assessment of certolizumab pegol (NICE 2019 [31]). The guidelines allow for the use of other TNF- $\alpha$ inhibitors in that period (ACR 2020 [26], Dutch Guidelines [27]), and recommend discontinuing the use of drugs from other therapeutic groups (Table 3) (ACR 2020 [26]).

\section{Pregnancy}

The use of biological drugs in pregnant psoriasis patients was referred to in five of the guidelines. The latest BAD 2020 guidelines [25] and ACR 2020 clinical practice guidelines [26] indicate that certolizumab pegol should be considered as first-choice treatment in pregnant women and can be used throughout the entire pregnancy. According to guidelines, treatment discontinuation during pregnancy is recommended in the case of secukinumab and ustekinumab (ACR 2020 [26]). Adalimumab, infliximab and etanercept should not be used during the $2^{\text {nd }}$ and $3^{\text {rd }}$ trimester of pregnancy (BAD 2020 [25], ACR 2020 [26], Dutch Guidelines [27]). The guidelines do not make references to the use of risankizumab, 
Table 3. Summary of recommendations for treatment of psoriasis with biological drugs during pregnancy planning

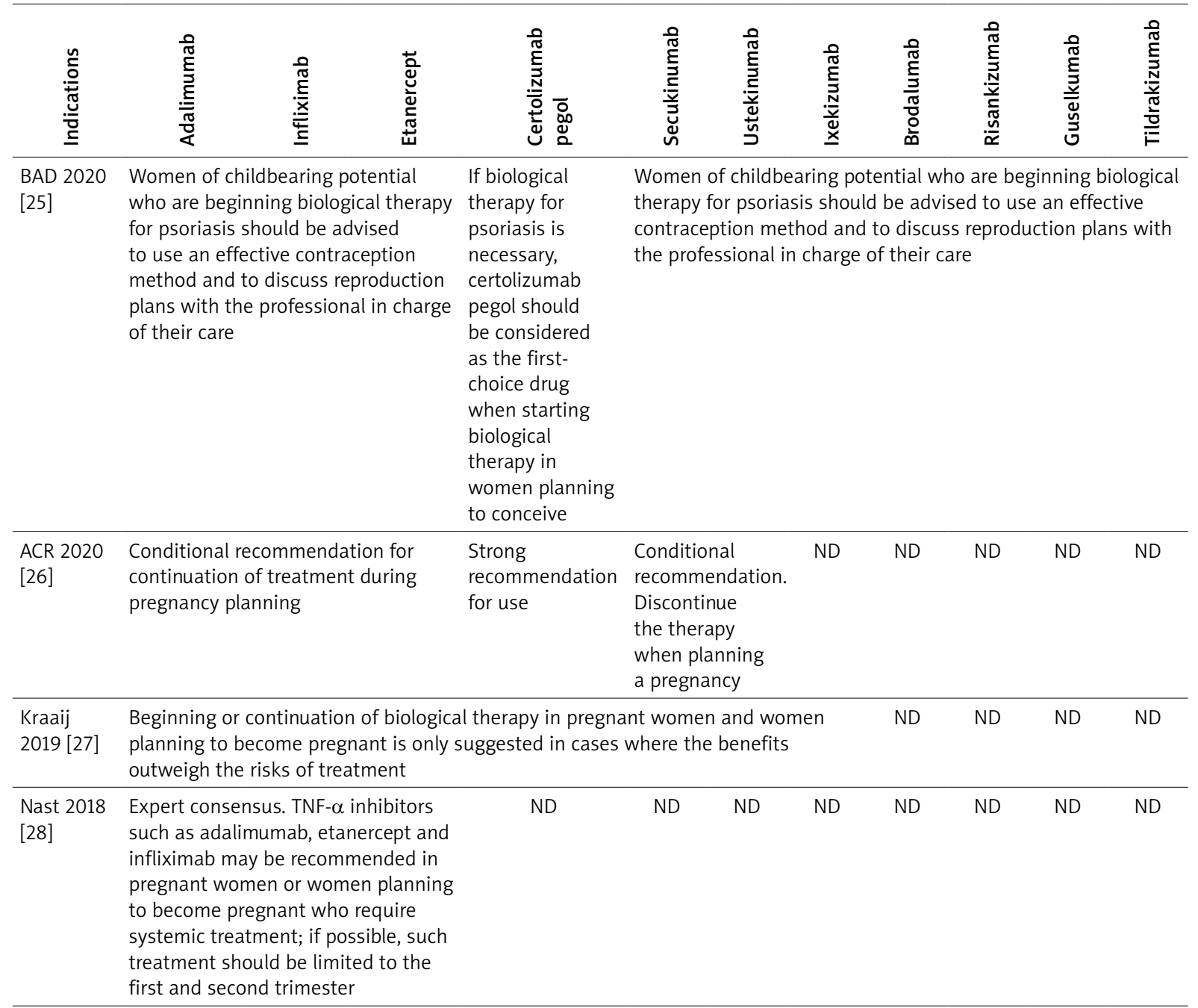

guselkumab, tildrakizumab and brodalumab by pregnant patients (Table 4).

\section{Lactation}

The use of biological drugs in breastfeeding psoriasis patients was referred to in three of the guidelines. The ACR 2020 guidelines [26] included a strong recommendation for biological treatment during lactation (treatment continuation or initiation), while two other documents allow for such a possibility after all pros and cons are considered (Table 5) (BAD 2020 [25], Latin American Clinical practice guidelines [28]).

\section{Discussion}

The action of most monoclonal antibodies used in psoriasis therapy is that of maternal antibodies, however their placenta permeability is not identical [12]. Active transport of biological drugs containing a fragment of Fc lgG1 depends on the placental Fc receptor. In the first trimester of pregnancy, when the foetal trophoblast does not produce Fc receptors yet, biological drugs have a limited ability to cross the placenta. Before week 14 of pregnancy, biological drug molecules enter the foetus through passive diffusion and only insignificant volumes reach the foetus during embryogenesis (first 12 weeks of pregnancy). However, from the second trimester, the crossing of biological drugs is facilitated by an increased expression of trophoblast Fc receptors, and IgG transport is most intense in the third trimester of pregnancy, as a result of which neonatal lgG1 levels are often higher than maternal levels [32-34]. TNF- $\alpha$ inhibitors (etanercept, infliximab, adalimumab, golimumab and certolizumab pegol) are the most researched biological agents in terms of use by pregnant women. Their different structure causes differences in the placental permeability. Etanercept is a soluble fusion protein. Infliximab, golimumab and adalimumab are TNF- $\alpha$-specific monoclonal IgG1 antibodies. Certolizumab pegol is a pegylated Fab fragment that does not contain an Fc moiety, therefore this drug is not bound to the placental Fc receptor [35]. 
Table 4. Summary of recommendations for treatment of psoriasis with biological drugs during pregnancy

\begin{tabular}{|c|c|c|c|c|c|c|c|c|c|c|c|}
\hline 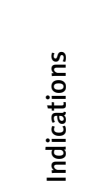 & 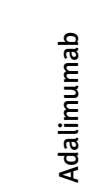 & 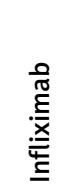 & 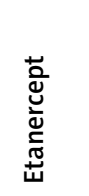 & 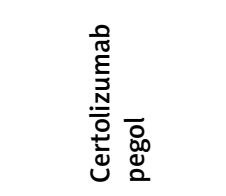 & 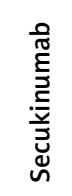 & 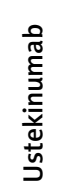 & $\begin{array}{l}\stackrel{0}{\widetilde{v}} \\
\stackrel{5}{\tilde{N}} \\
\underline{\underline{v}} \\
\underline{\underline{x}}\end{array}$ & $\begin{array}{l}\frac{0}{\widetilde{\varpi}} \\
\frac{5}{5} \\
\frac{\pi}{0} \\
\frac{0}{0}\end{array}$ & 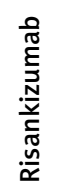 & 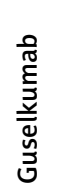 & 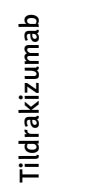 \\
\hline $\begin{array}{l}\text { BAD } \\
2020 \\
{[25]}\end{array}$ & \multicolumn{3}{|c|}{$\begin{array}{l}\text { Treatment discontinuation } \\
\text { during the second/third } \\
\text { trimester of pregnancy } \\
\text { should be considered. See: } \\
\text { certolizumab pegol }\end{array}$} & $\begin{array}{c}\text { Using } \\
\text { cyclosporine or } \\
\text { certolizumab } \\
\text { pegol as a first- } \\
\text { line option should } \\
\text { be considered } \\
\text { when systemic } \\
\text { treatment needs } \\
\text { to be initiated } \\
\text { in the second or } \\
\text { third trimester of } \\
\text { pregnancy }\end{array}$ & & & & ND & ND & ND & ND \\
\hline $\begin{array}{l}\text { ACR } \\
2020 \\
{[26]}\end{array}$ & \multicolumn{3}{|c|}{$\begin{array}{l}\text { Conditional } \\
\text { recommendation. } \\
\text { Continuation of therapy } \\
\text { in the first and second } \\
\text { trimester; discontinuation in } \\
\text { the third trimester, several } \\
\text { half-life periods before birth }\end{array}$} & $\begin{array}{l}\text { Strong } \\
\text { recommendation } \\
\text { for use }\end{array}$ & \multicolumn{2}{|c|}{$\begin{array}{l}\text { Discontinue } \\
\text { the therapy for } \\
\text { the period of } \\
\text { pregnancy }\end{array}$} & ND & ND & ND & ND & ND \\
\hline $\begin{array}{l}\text { Kraaij } \\
2019 \\
{[27]}\end{array}$ & \multicolumn{11}{|c|}{$\begin{array}{l}\text { Initiating continuation of biological therapy in pregnant women and women planning to conceive is only suggested in cases } \\
\text { where the benefits outweigh the risks of treatment. In such cases a slight preference in favour of etanercept occurs, taking } \\
\text { into account the short half-life period and the relatively low transfer through the placenta to the foetus. It is recommended } \\
\text { to discontinue the use of biological drugs, especially lgG immunoglobulins such as infliximab and adalimumab, before the } \\
\text { end of the second trimester in order to minimise the risk of immunosuppression in newborns }\end{array}$} \\
\hline $\begin{array}{l}\text { Nast } \\
2018 \\
{[29]}\end{array}$ & \multicolumn{3}{|c|}{$\begin{array}{l}\text { Expert consensus. } \\
\text { TNF- } \alpha \text { inhibitors such as } \\
\text { adalimumab, etanercept } \\
\text { and infliximab may be } \\
\text { recommended in pregnant } \\
\text { women or women planning } \\
\text { to conceive who require } \\
\text { systemic treatment; if } \\
\text { possible, such treatment } \\
\text { should be limited to the first } \\
\text { and second trimester }\end{array}$} & ND & ND & ND & ND & ND & ND & ND & ND \\
\hline $\begin{array}{l}\text { Kogan } \\
2019 \\
{[28]}\end{array}$ & \multicolumn{11}{|c|}{$\begin{array}{l}\text { The expert panel analysed the uncertainty regarding the safety of biological drugs in pregnant or breastfeeding women and } \\
\text { their foetus or newborns. } \\
\text { Treatment of pregnant or breastfeeding patients may be considered when short-term efficacy is a priority (e.g. severe disease } \\
\text { and patients who do not respond to cyclosporine) }\end{array}$} \\
\hline
\end{tabular}

Binding affinity of neonatal Fc receptor on placental trophoblast cells is highest for complete monoclonal antibodies such as infliximab and adalimumab, low for etanercept and absent for certolizumab pegol [36].

Information on the possibility of using biological drugs in women planning a pregnancy, patients who are pregnant or during lactation is limited. The possibility of determining therapeutic options in planning an individualized approach to patients planning a pregnancy and during the pregnancy period is based on individual reports from clinical trials and current clinical guidelines. As part of the analysis, medical information databases were searched for reliable clinical practice guidelines based on the methodol- ogy developed by the GRADE Group, which had reviewed existing evaluation systems and developed its own system of evaluating evidence and strength of recommendations which eliminates the methodological shortcomings of earlier systems [24]. In developing clinical practice guidelines, this methodology is used by an increasing number of specialist associations (EULAR, ACR) or the WHO (the full list of organisations supporting the methodology is available on http://www.gradeworkinggroup.org) [24].

Despite constituting the basis for using a drug in accordance with indications covered by marketing authorisations, information included in the SPCS might not include the latest clinical practice data regarding the use of 
Table 5. Summary of recommendations for treatment of psoriasis with biological drugs during lactation

\begin{tabular}{|c|c|c|c|c|c|c|c|c|c|c|c|}
\hline 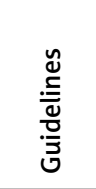 & $\begin{array}{l}\frac{0}{\sigma} \\
\frac{E}{5} \\
\frac{E}{E} \\
\frac{\pi}{0} \\
\frac{0}{4}\end{array}$ & 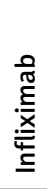 & 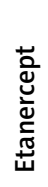 & 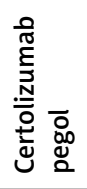 & 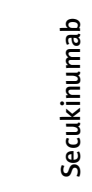 & 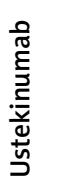 & 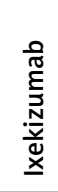 & $\begin{array}{l}\frac{0}{\overparen{T}} \\
\frac{5}{5} \\
\frac{\pi}{0} \\
\frac{0}{\infty}\end{array}$ & 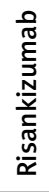 & 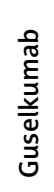 & 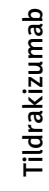 \\
\hline $\begin{array}{l}\text { BAD } \\
2020 \\
{[25]}\end{array}$ & \multicolumn{11}{|c|}{ The continuation or resumption of biological therapy in women wishing to breastfeed should be considered } \\
\hline $\begin{array}{l}\text { ACR } \\
2020 \\
{[26]}\end{array}$ & \multicolumn{4}{|c|}{ Strong recommendation for use } & $\begin{array}{r}\mathrm{C} \\
\text { recor } \\
\text { conce } \\
\text { drug in }\end{array}$ & $\begin{array}{l}\text { al } \\
\text { tion. } \\
\text { of the } \\
\text { ould be }\end{array}$ & ND & ND & ND & ND & ND \\
\hline $\begin{array}{l}\text { Kogan } \\
2019 \\
{[28]}\end{array}$ & \multicolumn{11}{|c|}{$\begin{array}{l}\text { The expert panel analysed the uncertainty regarding the safety of biological drugs in pregnant or breastfeeding women } \\
\text { and their foetus or newborns. Treatment of pregnant or breastfeeding patients may be considered when short-term } \\
\text { efficacy is a priority (e.g. severe disease and patients who do not respond to cyclosporine) }\end{array}$} \\
\hline
\end{tabular}

drugs. Based on adalimumab, etanercept and infliximab SPCs, it is possible to use this drug during pregnancy if clearly needed, and for certolizumab pegol if clinically needed. For adalimumab and certolizumab pegol, their SPCS allow use during lactation. It is recommended to refrain from using the other drugs in the pregnancy (ustekinumab, brodalumab, ixekizumab, secukinumab, guselkumab, risankizumab, tildrakizumab) [4].

Most clinical trials which tested the drugs in question for psoriasis treatment excluded pregnant patients, mostly for ethical reasons. It is one of the reasons for the lack of adequate data regarding safety of these therapies in women planning pregnancy and those who are pregnant or during lactation $[6,37,38]$. The majority of data on safety comes from studies in animals as well as registries and retrospective studies. Despite the awareness of the limitations associated with credibility of such evidence, more and more data suggest that biological drugs can be safely used in the treatment of psoriasis in the pregnant patients [37, 39-42].

The majority of data on the use of TNF- $\alpha$ inhibitors comes from rheumatological and gastroenterological studies [32, 38, 40, 43]. These drugs are most often used to treat diseases such as rheumatoid arthritis and inflammatory bowel disease. Given the placental transmission rate of antibodies, discontinuation of infliximab and adalimum$\mathrm{ab}$ treatment in week 20 of pregnancy is recommended. If treatment is continued after that time, it is recommended that infants should not be vaccinated using live vaccines in the first 6 months of life $[44,45]$. For structural reasons, etanercept and certolizumab pegol are characterised by significantly lower transmission and thus can be administered until a later pregnancy stage: etanercept up to week 30-32 and throughout the entire pregnancy for certolizumab pegol $[44,46]$. Treatment continuation should each time be discussed individually with the patients, taking all risks and benefits into account [38]. No conclusions can be drawn now on the safety of using ustekinumab and secukinumab prior to and during pregnancy due to the lack of relevant data [37].

Certolizumab pegol is the only biological drug for which a safety profile during pregnancy and lactation has been confirmed. The conclusions are derived from the analysis of the molecule structure and based on data collected from 528 pregnant and breastfeeding patients [42]. This has been reflected in the latest BAD 2020 [25] and ACR 2020 [26] guidelines. Two published prospective studies have demonstrated lack of placenta permeability of certolizumab pegol and transfer from the mother to the child (CRIB) in women in the third trimester [43] and the lack of minimal transfer from the mother's plasma to her breast milk (CRADLE) [41]. No teratogenic effects of certolizumab pegol compared to the general US and EU population, nor an increased mortality rate of the foetus have been observed [42].

NICE 2019 recommendations [31] indicate that certolizumab pegol can be used before and during pregnancy if it is clinically justified. Representatives of patients have indicated that pregnant women or women planning to conceive are willing to use systemic treatment which can be used throughout pregnancy and breastfeeding [31].

The existing data suggest very low concentrations of adalimumab, infliximab as well as etanercept in breast milk $[47,48]$. The concentration of certolizumab pegol is virtually undetectable [49]. These data provide the basis for continuing treatment with these drugs during lactation. Given the fact that all those drugs are in fact protein molecules, they are probably eliminated by acids and proteolytic enzymes present in the infant's gastrointestinal tract [50]. However, one should take into account the local impact on the gastrointestinal mucosa and even the risk of irritation [47]. The analysed data provide the basis for continuing treatment during lactation. In each case, the decision must be made on an individual risk-benefit basis. Careful monitoring of the mother and the infant is necessary during therapy [37, 49]. 
Pregnancy in a psoriasis patient raises concerns about the impact of maternal disease and therapy used on foetal development, but also the effect of discontinuation of therapy used on the mother's health and the severity of the disease process. Although most women experience clinical improvement in the disease, in some cases deterioration of skin lesions is observed. TNF- inhibitors seem to be the safest option for treating psoriasis, and the increasing amount of evidence suggests lack of teratogenicity, phototoxicity and embryotoxicity of that treatment. In this therapeutic group, certolizumab pegol is most likely the safest alternative due to non-existent or minimal placental permeability compared to other TNF- $\alpha$ inhibitors. In the case of other biological treatment from other drug groups (i.a. drugs blocking the p40 IL-12/IL-23 subunit - ustekinumab, anti-IL-17A antibodies secukinumab, ixekizumab), their use in this period should be limited to exceptional and special circumstances only.

\section{Acknowledgments}

CEESTAHC received support from UCB Pharma in the form of an educational grant ensuring CEESTAHC full independency. The donor did not play any role in designing methodology of literature review, collection and analysis of data or taking the decision on whether to prepare or publish the paper.

\section{Conflict of interest}

The authors declare no conflict of interest.

\section{References}

1. Parisi R, Symmons DPM, Griffiths CEM, Ashcroft DM. Global epidemiology of psoriasis: a systematic review of incidence and prevalence. J Investig Dermatol 2013; 133: 377-85.

2. Borzęcki A, Koncewicz A, Raszewska-Famielec M, DudraJastrzębska M. Epidemiology of psoriasis in the years 2008-2015 in Poland. Dermatol Rev 2018; 105: 693-700.

3. Reich A, Adamski Z, Chodorowska G, et al. Psoriasis. Diagnostic and therapeutic recommendations of the Polish Dermatological Society. Part I: mild psoriasis. Dermatol Rev 2018; 105: 225-43.

4. Gottlieb AB, Ryan C, Murase JE. Clinical considerations for the management of psoriasis in women. Int I Womens Dermatol 2019; 5: 141-50.

5. Raychaudhuri SP, Navare T, Gross J, Raychaudhuri SK. Clinical course of psoriasis during pregnancy. Int J Dermatol 2003; 42: 518-20.

6. Bobotsis R, Gulliver WP, Monaghan K, et al. Psoriasis and adverse pregnancy outcomes: a systematic review of observational studies. Br J Dermatol 2016; 175: 464-72.

7. Vena GA, Cassano N, Bellia G, Colombo D. Psoriasis in pregnancy: challenges and solutions. Psoriasis 2015; 5: 83-95.

8. Announcement of the Minister of Health of 18 February 2020 on the list of reimbursed drugs, foodstuffs for particular nutritional uses and medical devices as at 1 March 2020 - Ministry of Health - Gov.pl. Accessed on: https://www.gov.pl/web/zdrowie/obwieszczenie-ministrazdrowia-z-dnia-18-lutego-2020-r-w-sprawie-wykazu-refundowanych-lekow-srodkow-spozywczych-specjalnego- przeznaczenia-zywieniowego-oraz-wyrobow-medycznychna-1-marca-2020-r (5.6.2020).).

9. English language version of Summary of Product Characteristics for Humira (adalimumab). Accessed: https://www. ema.europa.eu/en/documents/product-information/humira-epar-product-information_en.pdf.

10. English language version of Summary of Product Characteristics for Enbrel (etanercept). Accessed: https:// ec.europa.eu/health/documents/community-register/2019/20191114146217/anx_146217 en.pdf.

11. English language version of Summary of Product Characteristics for Cimzia (certolizumab). Accessed: https:// ec.europa.eu/health/documents/community-register/2020/20200626148570/anx_148570_en.pdf.

12. Rademaker M, Agnew K, Andrews M, et al. Psoriasis in those planning a family, pregnant or breast-feeding. The Australasian Psoriasis Collaboration. Australas I Dermatol 2018; 59: 86-100.

13. Ferreira C, Azevedo A, Nogueira M, Torres T. Management of psoriasis in pregnancy - a review of the evidence to date. Drugs Context 2020; 9: 2019-11-6.

14. FDA Pregnancy Categories.

15. Australian categorisation system for prescribing medicines in pregnancy. Accessed: https://www.tga.gov.au/ australian-categorisation-system-prescribing-medicinespregnancy.

16. English language version of Summary of Product Characteristics for Remicade (infliximab). Accessed: https:// ec.europa.eu/health/documents/community-register/2019/20191024146198/anx_146198_en.pdf.

17. English language version of Summary of Product Characteristics for Stelara (ustekinumab). Accessed: https:// www.ema.europa.eu/en/documents/product-information/ stelara-epar-product-information_en.pdf.

18. English language version of Summary of Product Characteristics for Cosentyx (secukinumab). Accessed: https:// www.ema.europa.eu/en/documents/product-information/ cosentyx-epar-product-information_en.pdf.

19. English language version of Summary of Product Characteristics for Taltz (ixekinumab). Accessed: https:// ec.europa.eu/health/documents/community-register/2017/20171208139360/anx_139360_en.pdf.

20. English language version of Summary of Product Characteristics for Skyrizi (risankizumab). Accessed: https://www. ema.europa.eu/en/documents/product-information/skyrizi-epar-product-information en.pdf.

21. English language version of Summary of Product Characteristics for Tremfya (guselkumab). Accessed: https://www. ema.europa.eu/en/documents/product-information/tremfya-epar-product-information_en.pdf.

22. English language version of Summary of Product Characteristics for llumetri (tildrakizumab). Accessed: https:// www.ema.europa.eu/en/documents/product-information/ ilumetri-epar-product-information_en.pdf.

23. English language version of Summary of Product Characteristics for Kyntheum (brodalumab). Accessed: https:// www.ema.europa.eu/en/documents/product-information/ kyntheum-epar-product-information_en.pdf.

24. GRADE Working Group. The Grading of Recommendations Assessment, Development and Evaluation (GRADE) Working Group website. Accessed: http://www.gradeworkinggroup.org/ (5.6.2020).

25. Smith CH, Yiu ZZ, Bale T, et al. British Association of Dermatologists guidelines for biologic therapy for psoriasis 2020 - a rapid update. Br J Dermatol 2020; 183: 628-37. 
26. Sammaritano LR, Bermas BL, Chakravarty EE, et al. 2020 American College of Rheumatology Guideline for the Management of Reproductive Health in Rheumatic and Musculoskeletal Diseases. Arthritis Care Res 2020; 72: 461-88.

27. Kraaij GE, Balak DMW, Busard Cl, et al. Highlights of the updated Dutch evidence- and consensus-based guideline on psoriasis 2017. Br J Dermatol 2019; 180: 31-42.

28. Kogan N, Raimondo N, Gusis SE, et al. Latin American Clinical Practice Guidelines on the Systemic Treatment of Psoriasis SOLAPSO - Sociedad Latinoamericana de Psoriasis (Latin American Psoriasis Society). Int J Dermatol 2019; 58 (Suppl 1): 4-28.

29. Nast A, Amelunxen L, Augustin M, et al. S3 Guideline for the treatment of psoriasis vulgaris, update - Short version part 1 - systemic treatment. J Dtsch Dermatol Ges 2018; 16 : 645-69.

30. Notes on Prescribing Medications for Rheumatic Diseases in Pregnancy. Australian Rheumatology Association 2018. Accessed: https://rheumatology.org.au/gps/documents/ ARAPregnancyPrescribingnotes151018final 000.pdf.

31. NICE. (2019) Evidence-based recommendations on certolizumab pegol (Cimzia) for treating moderate to severe plaque psoriasis in adults. Accessed: https://www. nice.org.uk/guidance/ta574/resources/certolizumabpegol-for-treating-moderate-to-severe-plaque-psoriasispdf-82607142805189.

32. Mahadevan U, Wolf DC, Dubinsky M, et al. Placental transfer of anti-tumor necrosis factor agents in pregnant patients with inflammatory bowel disease. Clin Gastroenterol Hepatol 2013; 11: 286-92.

33. Suzuki T, Ishii-Watabe A, Tada M, et al. Importance of neonatal FcR in regulating the serum half-life of therapeutic proteins containing the Fc domain of human IgG1: a comparative study of the affinity of monoclonal antibodies and Fc-fusion proteins to human neonatal FcR. J Immunol 2010; 184: 1968-76.

34. Soh MC, Moretto M. The use of biologics for autoimmune rheumatic diseases in fertility and pregnancy. Obstet Med 2019; https://doi.org/10.1177/1753495X19841799.

35. Porter C, Armstrong-Fisher S, Kopotsha T, et al. Certolizumab pegol does not bind the neonatal Fc receptor (FcRn): consequences for FcRn-mediated in vitro transcytosis and ex vivo human placental transfer. J Reprod Immunol 2016; 116: 7-12.

36. Förger F. Treatment with biologics during pregnancy in patients with rheumatic diseases. Reumatologia 2017; 55: 57-8.

37. Plachouri KM, Georgiou S. Special aspects of biologics treatment in psoriasis: management in pregnancy, lactation, surgery, renal impairment, hepatitis and tuberculosis. J Dermatol Treat 2019; 30: 668-73.

38. Pottinger E, Woolf RT, Exton LS, et al. Exposure to biological therapies during conception and pregnancy: a systematic review. Br J Dermatol 2018; 178: 95-102.

39. Hyrich KL, Verstappen SMM. Biologic therapies and pregnancy: the story so far. Rheumatology 2014; 53: 1377-85.

40. Ali YM, Kuriya B, Orozco C, et al. Can tumor necrosis factor inhibitors be safely used in pregnancy? J Rheumatol 2010; 37: 9-17.

41. Clowse ME, Förger F, Hwang C, et al. Minimal to no transfer of certolizumab pegol into breast milk: results from CRADLE, a prospective, postmarketing, multicentre, pharmacokinetic study. Ann Rheum Dis 2017; 76: 1890-6.

42. Clowse MEB, Scheuerle AE, Chambers C, et al. Pregnancy outcomes after exposure to certolizumab pegol: updated results from a pharmacovigilance safety database. Arthritis Rheumatol 2018; 70: 1399-407.

43. Mariette X, Förger F, Abraham B, et al. Lack of placental transfer of certolizumab pegol during pregnancy: results from CRIB, a prospective, postmarketing, pharmacokinetic study. Ann Rheum Dis 2018; 77: 228-33.

44. S3-Leitlinie zur Therapie der Psoriasis vulgaris Update - 2017. Accessed: https://www.awmf.org/uploads/ tx_szleitlinien/013001I_S3_Therapie_Psoriasis-vulgaris_2017-12.pdf.

45. Skorpen CG, Hoeltzenbein M, Tincani A, et al. The EULAR points to consider for use of antirheumatic drugs before pregnancy, and during pregnancy and lactation. Ann Rheum Dis 2016; 75: 795-810.

46. Horst S, Kane S. The use of biologic agents in pregnancy and breastfeeding. Gastroenterol Clin North Am 2014; 43: 495-508.

47. Ben-Horin S, Yavzori M, Kopylov U, et al. Detection of infliximab in breast milk of nursing mothers with inflammatory bowel disease. J Crohns Colitis 2011; 5: 555-8.

48. Keeling S, Wolbink GJ. Measuring multiple etanercept levels in the breast milk of a nursing mother with rheumatoid arthritis. J Rheumatol 2010; 37: 1551.

49. Witzel SJ. Lactation and the use of biologic immunosuppressive medications. Breastfeed Med 2014; 9: 543-6.

50. Peddlesden J. Drugs in breastmilk. Pharmacy Practice 2005. 